\title{
Materyalist Eğilimlerin Tüketici Yenilikçiliği Üzerindeki Etkilerinin Belirlenmesi ve Demografik Değişkenler Açısından İncelenmesi
}

\author{
Esra Özkan Pira, b
}

Özet

Çalışmanın amacı; toplumdaki bireylerin materyalist eğilimlerinin tüketici yenilikçiliği üzerindeki etkilerinin belirlenmesidir. Mevcut araştırmanın örneklemini 2019 yılında Erzincan'da ikamet eden halk oluşturmaktadır. Çalışmada; materyalist eğilim ölçeği ve tüketici yenilikçiliği ölçeği kullanılmıştır. Ankette demografik değişkenler dahil olmak üzere toplam 33 soru bulunmaktadır. Materyalist eğilimler ve tüketici yenilikçiliği değişkenleri ile katılımcıların demografik özellikleri arasındaki ilişkiler incelenmiştir. Analizler SPSS paket programı kullanılarak elde edilmiştir. İki bölümden oluşan araştırmanın ilk bölümünde ilgili literatüre değinilmiş ve kavramlar arası ilişkiler açıklanmıştır. İkinci bölümde araştırma hipotezleri analiz edilmiştir. Araştırma sonuçlarına göre Erzincan ilindeki halkın materyalist eğilimleri arttıkça tüketici yenilikçiliği de artmaktadır. Demografik değişkenlere ile materyalist eğilimler ve tüketici yenilikçiliğine ilişkin çeşitli farklılıklar elde edilmiş ve yorumlanmıştır.
Anahtar Kelimeler

Materyalizm

Materyalist Eğilimler

Tüketici Yenilikçiliği

Makale Hakkında

Geliş Tarihi: 13.03.2019

Kabul Tarihi: 25.12.2020

Doi: 10.18026/cbayarsos.539112

\section{Determination and Analysis of the Effects of Materialist Tendencies on Consumer Innovation in Terms of Demographic Variables}

\begin{abstract}
The aim of the study was the determination of the effects of the materialist tendencies of individuals in society on consumer innovation. The sample of the present study was comprised of the people residing in Erzincan in 2019. In the study, the materialist tendency scale and consumer innovation scale were used. There are a total of 33 questions in the questionnaire including demographic variables. Relationships between materialist tendencies and consumer innovation variables and demographic characteristics of the participants were examined. The analyses were performed using the SPSS package program. In the first part of the study, which consisted of two parts, the relevant literature was discussed, and the relationships between concepts are explained. In the second part, the research hypotheses were analyzed. According to the results of the research, as the materialist tendencies of the people residing in Erzincan province increased, consumer innovation also increased. Various differences regarding demographic variables, materialistic tendencies, and consumer innovation were determined and interpreted.
\end{abstract}

Keywords

Materialism

Materialist Tendencies

Consumer Innovation

About Article

Received: 13.03.2019

Accepted: 25.12.2020

Doi: 10.18026/cbayarsos.539112

a esraozkanpir@gmail.com

b Dr. Öğretim Üyesi, Erzincan Binali Yıldırım Üniversitesi, Erzinan, 0000-0002-1271-7397 


\section{Introduction}

Today, the demands and needs of consumers are constantly under the influence of change and innovation. Consumption becomes vital for consumers, enterprises, marketers, and even the government. Consumers obtain social status thanks to their consumption and the social status obtained becomes an identity for the consumer (Bocock, 2009: 24).

Individuals have been interacting with material and spiritual objects in all areas of their lives from past to present. In fact, they often formed an emotional bond with various items such as cars and houses. Most of the time, these items have been used as a means of identity, status, and show by people and are still used. Today, people value materials more than they should. It is known that in developed societies, people attach importance to status in order to show their position in society or obtain a certain position, and they aim to gain a reputation by consuming products based on materiality and with high-status indicators. Materialism is defined as the relationship of the individual with the economic goods that actually exist, and which they desire. In another perspective, while materialism is defined as an attitude towards consumption, it is the emergence of ownership, desire, and attraction towards things as an ongoing belief.

Materialists judge themselves and others by the size of their possessions and think that they can find happiness and joy by consuming expensive products. Materialist tendency, brand awareness, the pursuit of luxury and comfort, symbolic consumption, etc. play significant role in decision making and purchases by forming the basis of behavior.

Marketing researchers consider the types of innovativeness as perceived or realized innovativeness. In the late 1970s, researchers began to define innovativeness as a personality trait, Midgley and Dowling (1978) pointed out that innovativeness has a hypothetical nature by its unobservable definition (Vandecasteele and Geuens, 2010: 308).

New product development is one of the factors that provide a sustainable competitive advantage to businesses (Porter, 1998: 50-51). Today, innovativeness stands out as an important element in the firm's ability to gain competitive advantage and to sustain its existence (Batory et al., 2005). On the other hand, it is a fact that most of the new products are not adopted by the consumers and this situation causes serious time and cost loss for the enterprises (Güleş and Bülbül, 2004). For this reason, it should not be forgotten that new products turn into a resource that provides a competitive advantage to the enterprises only when they are adopted by the consumers.

It will be an important guide for enterprises to know who tend to consume innovations first, in making marketing decisions. With this information, the answers to many questions such as what the innovation should include, how it will be positioned, how to distribute, how to price, how to do media planning, whether the customer should be trained to use innovation, may arise. Thanks to the correct marketing of the innovation, the enterprise that first created the innovation will gain the greatest benefit from it. The first step in marketing innovation correctly is defining innovative consumers and understanding their behavior (Akdoğan and Karaaslan, 2013, s. 3). It is suggested in the literature that consumer innovativeness is related to consumer behavior and characteristics. It is seen that consumer innovativeness is a concept that is examined both at the level of individual and a specific product category.

The sample of the present study was comprised of the people residing in Erzincan in 2019. In the study, the materialist tendency scale and consumer innovation scale were used. 
Relationships between materialist tendencies and consumer innovation variables and demographic characteristics of the participants were examined. In the first part of the study, which consisted of two parts, the relevant literature was discussed, and the relationships between concepts are explained. In the second part, the research hypotheses and analyses were performed using the SPSS package program. According to the results of the research, as the materialist tendencies of the people residing in Erzincan province increased, consumer innovation also increased. Various differences regarding demographic variables, materialistic tendencies, and consumer innovation were determined and the results obtained are given in detail in the conclusion of the research.

\section{Literature Rewiev}

In economics, psychology and consumer researches, materialism is mostly defined as the importance given to worldly beings by the consumer or as a tendency towards materiality and money, which is seen as important for personal happiness and social progress (Aydin, 2009: 20). Numerous studies that examine the relationships between the materialistic values of individuals and their consumption behavior from different perspectives take place in the marketing literature. Materialism and happiness relationship (Belk, 1984), status consumption and materialism relationship (Eastman et al. 1997, Heaney et al. 2005), materialism, debt, saving and spending relationships (Watson, 2003) are a few examples of the aforementioned research.

Richins and Dawson conceptualized materialism as a value. Defining materialism as a value is consistent with the idea that materialism reflects the importance given to one's wealth. For materialists, properties and their purchases are at the forefront of personal goals that define the "way of life". They value their assets and purchases more than many other issues and activities in life (Richins and Dawson, 1992). Kasser states that materialism is a fundamental aspect of the human value system (Kasser, 2018).

Materialism is defined as "individuals' seeing money and materials as a path to personal happiness and social progress". According to Belk, people with high materialistic values place the material assets they have or cannot have at the center of their lives, and they also point to these assets as the biggest cause of satisfaction or dissatisfaction in their lives (Doğan, 2010: 58). Materialist consumers want to create a permanent image in the eyes of other people, and they also get help from the images of certain products and brands to create an image (Fitzmaurice and Comegys, 2006: 289). Owning makes individuals happy, but possesions gain more importance than people. Materialist individuals; they seem extremely passionate about preserving their possessions like souvenirs or objects with a memory and attaching to them (Titay and Torlak, 2011: 96).

Luxury consumption is attractive particularly for materialistic consumers. First, materialists highlight their existence as a sign of success and wealth against other people, and often materialists aim to form their image and identity as they wish, through luxury consumption (Hudders and Pandelaere, 2012: 415). Today, three common points of theories to explain materialism, which is generally accepted as a psychological and sociological phenomenon, draw attention (Odabaşı, 2013: 109):

- Materialism as an Indicator of Success: Many of the individuals with materialist tendencies evaluate their own or others' achievements according to the property and money they have. 
- Ownership-Oriented Materialism: Individuals with materialist tendencies turn the goods and properties they own or want to own into life goals. Materialism is a lifestyle and a high level of material consumption in this life is an end rather than a tool.

- Materialism Focused on Reaching Happiness: An indispensable way for materialistic individuals to satisfy themselves and feel better; It passes from owning property and money. While many people can find happiness in personal relationships, experiences, and achievements, for these individuals all this has provided an important finding for marketers and macroeconomists, finding that it is closely related to saving, which is important enough.

Richins and Dawson (1992) stated that people with a high level of materialistic tendency in validation tests want a higher income level than people with a low level of materialistic tendency; They pointed out that they focus more on financial security and prefer to spend more on themselves and less on others, emphasizing less on interpersonal relationships. In this context, it can be said that highly materialistic people perform less voluntary simplicity behaviors and are less satisfied with their lives.

A different motivation is needed for each dimension of materialism. In the dimension of being successful, the individual thinks that he can reflect his success with the quality, quantity and characteristics of the goods he has. In the second dimension, the dimension of ownership, there is a materialistic acquisition in the center of the life of the individual, that is, having the products they want. In reaching the third dimension, happiness, the individual believes that he will be happier when he has it (Nepomuceno and Laroche. 2015: 4).

Materialist individuals value more for what they have, and the desire to have is more important to them than any other relationship and goal in their lives. The positive relationships between some personality traits (eg stinginess) and materialism show that materialistic individuals are self-centered. Materialist individuals choose a lifestyle in which they can have more things instead of a simple life (Sevgili, 2012: 26-27)

Materialism represents a set of minds or attitudes regarding the relative importance of the acquisition and possession of objects in an individual's life. For materialists, properties and their purchases are at the forefront of personal goals that define the "way of life". (Bindah and Othman, 2011: 239-240). Materialism can be characterized as a belief that shopping and consumption will lead people to happiness (Aydın, 2009: 22). Materialist and industrial society values have been replaced by post-materialist values. While economic security and welfare are important in the first value system, the prominent value in the second value system is "self-actualization" and "individualism" (Ventura, 2013: 82).

Consumer innovativeness is the tendency to buy new and different products or brands rather than previous preferences and consumption patterns (Steenkamp et al., 1999: 55). Elements that can be considered as innovations for consumers are evaluated as new products, new distribution methods, and new advertising methods, and innovative consumers act as an important tool in the spread of innovation (Odabaş1 and Barış, 2002: 284). In other words, innovativeness is a person's behavior relatively earlier than other people in adopting an innovation (Rogers and Shoemaker, 1971). Consumer innovativeness is the tendency to purchase different and new products and new brands instead of keeping previous preferences and consumption the same (Başar and Yaprakl1, 2013: 152). Consumer innovativeness is associated with consumer behaviors and characteristics such as socioeconomic, personality and communication (Xie and Singh, 2007). However, it includes the 
change in purchasing and consumption patterns. In addition, it has been determined that consumer innovativeness is related to the risk-taking ability of consumers (Merchant et al., 2014: 325).

Consumer innovativeness has been defined in various ways according to different perspectives in the literature and measured with different scales (Eryiğit and Kavak, 2011). Two important scales that are frequently encountered are Innate Innovativeness (Midgley and Dowling, 1978; Venkatraman, 1991; Im et al., 2007), which recognizes that innovativeness is an innate personality trait, and Interest-Specific Innovativeness, which deals with innovation on a specific product basis. (Domain Specific Innovativeness) (Goldsmith and Hofacker, 1991; Cowart et al., 2008). In general, personal innovativeness is the general level of innovativeness, whereas innovativeness specific to the area of interest is expressed as behavior that can be observed and measured as innovative behavior (Goldsmith and Flyn, 1993: 378, Hirunyawipada and Paswan, 2006: 182).

Aydin (2009) discusses the concept of consumer innovativeness at the level of personal characteristics and a certain product category, and the effect of personal characteristics and personal characteristics specific to the product category on the innovativeness dimension; Özer, Aydın and Özcan (2009), the effect of accountants' brand perception and consumer characteristics on innovation and thought leadership; Kılıçer and Odabaşı (2010) related to adapting the individual innovation scale developed by Thomas, Joseph and Cook (1976) into Turkish; Eryiğit and Kavak (2011), by determining consumer innovativeness with Bass diffusion model, interest-specific innovativeness scale and innate innovativeness scale, it is about whether attitude and behavior measures give similar results; Alan and Yeloğlu (2013) conducted studies to determine the relationship between branding and innovation.

There are many studies on consumer innovation in the literature. These studies aimed at adapting to the product and helped to discover the character of consumer innovation. For example Robertson and Myers (1969); Bruce and Witt (1970); Blake, Perloff and Heslin (1970); Studies of Tatham and Dornoff (1973) on the usual innovativeness conflicts, Feldman and Armstrong (1975), Peat, Gentry and Brown (1975) on the characteristics of major automobile innovation buyers and Pizam (1972); Engel, Kollat and Blackwell (1973) have empirical studies on consumer innovativeness according to sociodemographic behavior and personal factors.

\section{Methodology \\ The Purpose and Importance of the Research}

The aim of the research was to reveal the effect of consumers' materialist tendencies on consumer innovation. In addition, another aim of the study was to reveal the relationships of demographic data with variables and from which group or groups the differences that make up these relationships arose. 


\section{Research Model}

The research was designed to determine the relationship of consumers' materialist tendencies with consumer innovation and its effects. The main independent variable of the research was materialist tendencies, and the dependent variable was consumer innovation. The research model is as follows.

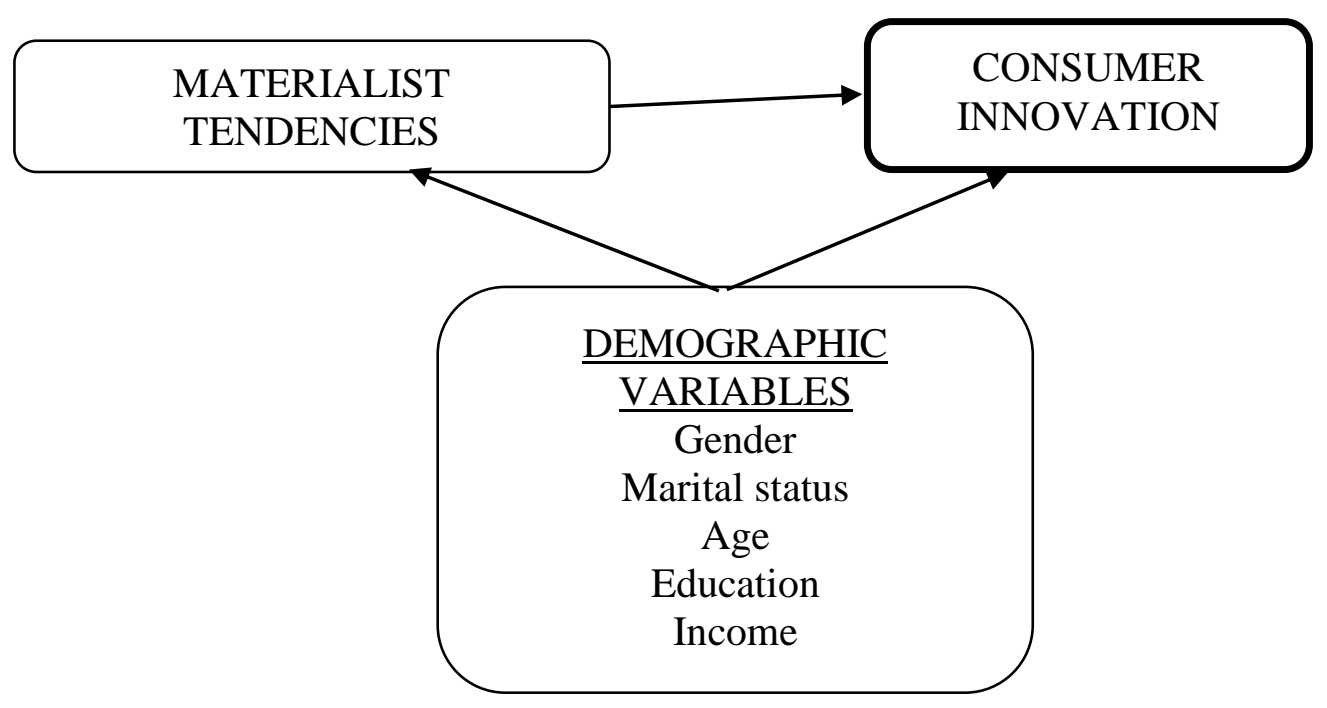

Figure 1. Research Model

The research hypotheses are as follows:

$H_{1}$ : Materialist tendencies have a statistically significant effect on customer innovation.

$\boldsymbol{H}_{2}$ : Materialist tendencies significantly differ according to the gender variable.

$\boldsymbol{H}_{3}$ : Consumer innovation displays a significant difference according to the gender variable.

H4: Materialist tendencies show a significant difference according to the marital status variable.

H5: Consumer innovation shows a significant difference according to the marital status variable.

$H_{6:}$ Materialist tendencies significantly differ according to the age variable.

$H_{7:}$ Consumer innovation displays a significant difference according to the age variable.

$H_{s:}$ Materialist tendencies differ significantly according to the education variable.

$H_{9:}$ Consumer innovation shows a significant difference according to the education variable.

$H_{10}$ : Materialist tendencies significantly differ according to the income variable.

$H_{11}$ : Consumer innovation displays a significant difference according to the income variable. 


\section{Research Sample and Data Collection Method}

The study group of the present study consisted of people residing in Erzincan in 2019. The sample of the study consisted of 286 consumers between the ages of 18-80 living in Erzincan. A simple random sampling method was used in sample selection. The questionnaire forms were handed out to the participants, and a total of 286 questionnaires were included in the study, as some of the questionnaires were not returned and some contained incomplete information. The data used in the study were obtained between 01.12.2019-28.12.2019.

\section{Scales Used in the Research and Analysis Method}

In the study, the materialist tendency scale and consumer innovation scale were used. The materialist tendency scale is the scale used by Ger and Belk, W.R. (1996) in their study and consists of 22 questions. In order to measure consumer innovation, a 6-item scale developed by Goldsmith and Hofacker (1991) was used. The scales are 5-point Likert type scales $(1=$ Strongly disagree, $5=$ Strongly agree). Cronbach's Alpha coefficient was used to determine the reliability of the scale. Demographic information was also included in the study. Within the scope of demographic data, gender, marital status, age, education, and income were examined. Correlation, regression, $\mathrm{t}$-test, and ANOVA analyses were performed to test the hypotheses in the study. The analyses were performed using the SPSS package program.

\section{Findings}

In this part of the research, percentage and frequency analyses of demographic variables of consumers, reliability analyses of scales, correlation and regression analysis results, t-test, and ANOVA results were included. Reliability analysis was performed to determine the reliability level of the scale used in the study, and the Cronbach's alpha coefficient was determined. If the evaluation criterion taken in the evaluation of Cronbach's Alpha Coefficient (Hulin et al., 2001) is

$0.00 \leq \alpha<0.40$, the scale is not reliable.

If it is $0.40 \leq \alpha<0.60$, the scale has low reliability.

If it is $0.60 \leq \alpha<0.80$, the scale is quite reliable.

If it is $0.80 \leq \alpha<1.00$, the scale is highly reliable.

According to Table 1, the Cronbach's Alpha coefficients of the variables are higher than 0.70 and it is possible to say that the scales are reliable.

Table 1. Reliability Analyses of the Scales

\begin{tabular}{lllll}
\hline No & Sub-Dimension & $\begin{array}{l}\text { Number of } \\
\text { Items }\end{array}$ & $\begin{array}{l}\text { Cronbach's } \\
\text { Alpha }\end{array}$ \\
\hline 1 & Materialist & Tendencies & 22 & 0.782 \\
\hline 2 & Consumer & Innovation & 6 & 0.910 \\
\hline
\end{tabular}

Cronbach's alpha value is 0.782 for the materialist tendency scale, and 0.910 for the consumer innovation scale.

Of the consumers participating in the research, $61.2 \%$ were female $(n=175)$ and $38.8 \%$ were male $(n=111) ; 69.9 \%$ were single $(n=200), 30.1 \%$ were married $(n=86) ; 41.6 \%$ were in the $18-30$ age range $(n=119), 28.7 \%$ in the $31-50$ age range $(n=82)$, and $29.7 \%$ were in the age 
group of 51 years and older $(\mathrm{n}=85)$. As regards the educational status, $38.5 \%$ had primary school education $(n=110), 28.0 \%$ were high school graduates $(n=80), 19.6 \%$ had associate degree $(n=56), 14.0 \%$ had undergraduate and postgraduate degrees $(n=40)$. As for income level, $10.5 \%$ of the participants had an income level of $1-1,000$ TL $(n=30), 64.7 \%$ were in the range of 1,001-2,500 TL $(n=185), 14.3 \%$ earned between 2,501 -4000 TL $(n=41)$ and $10.5 \%$ of them had an income of 4001 TL and above $(n=23)$.

Table 2 shows the correlation analysis between materialist tendency and consumer innovation.

Table 2. Correlation Analysis Results Regarding Materialist Tendency and Consumer Innovation

\begin{tabular}{|c|c|c|c|}
\hline & & $\begin{array}{l}\text { Materialist } \\
\text { Tendency }\end{array}$ & Consumer Innovation \\
\hline \multirow{3}{*}{$\begin{array}{l}\text { Materialist } \\
\text { Tendency }\end{array}$} & Correlation & 1 & $.187^{* *}$ \\
\hline & Sig. (p) & & \\
\hline & $\mathrm{N}$ & 286 & \\
\hline \multirow{3}{*}{$\begin{array}{l}\text { Consumer } \\
\text { Innovation }\end{array}$} & Correlation & $.187^{* *+}$ & 1 \\
\hline & Sig. (p) & .002 & \\
\hline & $\mathrm{N}$ & 286 & 286 \\
\hline
\end{tabular}

According to the findings in Table 2, there was a strong positive relationship $\left(\mathrm{r}=.187^{* *}\right)$ between materialist tendency and consumer innovation.

Table 3.Regression Analysis Results Regarding Materialist Tendency and Consumer Innovation

\begin{tabular}{|c|c|c|c|c|c|}
\hline \multirow[t]{2}{*}{ Model } & \multicolumn{5}{|c|}{ Consumer Innovation } \\
\hline & B & $\begin{array}{c}\text { Standard } \\
\text { Error }\end{array}$ & $\bar{\beta}$ & $\mathrm{t}$ & $p$ \\
\hline $\begin{array}{l}\text { Materialist } \\
\text { Tendency }\end{array}$ & 5.566 & 2.358 & 0.187 & 2.361 & 0.019 \\
\hline & $\mathrm{R}=0.187$ & $\mathrm{R}^{2}=0.035$ & $\begin{array}{l}\text { Durbin- } \\
\text { Watson } \\
1.530 \\
\end{array}$ & $=\begin{aligned} & F=10.265 \\
= & \end{aligned}$ & $\mathrm{p}=0.002$ \\
\hline
\end{tabular}

The results revealed that the regression model between materialist tendency and consumer innovation was significant $(F=10.265 ; \mathrm{p}=0.002)$.

Materialist tendencies had a statistically significant effect on consumer innovation ( $\beta=0.187$; $\mathrm{p}=0.002<0.05)$, and $\mathrm{H}_{1}$ was accepted.

According to the t-test and ANOVA, significant differences were determined between gender, marital status, age, education, income demographic variables, and materialist tendencies of consumers and consumer innovation. Parametric tests were used as the data showed a homogeneous distribution. 
Tables explaining this relationship are as follows:

Table 4.T-Test Results on Materialist Tendency and Consumer Innovation and Gender Variables

\begin{tabular}{|c|c|c|c|c|c|}
\hline \multirow[t]{2}{*}{ Variable } & \multicolumn{5}{|c|}{ Levene's Test for Equality of Variances } \\
\hline & $\mathbf{F}$ & Sig. & $\mathbf{t}$ & df & Sig. (2-tailed) \\
\hline \multirow{2}{*}{ Materialist Tendency } & .085 & .771 & .750 & 284 & .454 \\
\hline & & & .754 & 239.016 & .451 \\
\hline \multirow{2}{*}{ Consumer Innovation } & 6.117 & .014 & -4.955 & 284 & .000 \\
\hline & & & -4.797 & 209.386 & .000 \\
\hline
\end{tabular}

When Table 4 is examined, it is seen that there was no significant difference between the gender variable and materialist tendencies, while there was a significant difference between the gender variable and consumer innovation $(\mathrm{p}<0.05)$. In this case, while $\mathrm{H}_{2}$ was rejected, $\mathrm{H}_{3}$ was accepted. In order to understand from which group the gender difference in terms of consumer innovation arose, it is necessary to look at group statistics.

Table 5. Group Statistics on Consumer Innovation and Gender Variable

\begin{tabular}{llllrr}
\hline \multicolumn{7}{c}{ Group Statistics } \\
\hline Variable & Marital status & N & Mean & Standard Deviation & Standard Error \\
\hline \multirow{2}{*}{ Materialist Tendency } & Female & 175 & 75.3200 & 12.36190 & .93447 \\
\cline { 2 - 6 } & Male & 111 & 74.2072 & 12.02431 & 1.14130 \\
\hline \multirow{2}{*}{ Consumer Innovation } & Female & 175 & 11.5600 & 5.88936 & .44519 \\
\cline { 2 - 6 } & Male & 111 & 15.3243 & 6.80797 & .64618 \\
\hline
\end{tabular}

When the group statistics are examined, it is seen that consumer innovation tendency was higher in male consumers compared to females.

Table 6. T-Test Results on Materialist Tendency and Consumer Innovation and Marital Status Variables

\begin{tabular}{|c|c|c|c|c|c|c|}
\hline \multicolumn{7}{|c|}{$\begin{array}{c}\text { Levene's Test for Equality of } \\
\text { Variances }\end{array}$} \\
\hline Variable & $\mathbf{F}$ & & Sig. & $t$ & df & $\mathrm{p}$ \\
\hline \multirow{2}{*}{ Materialist Tendency } & & .375 & .541 & -.425 & 284 & .671 \\
\hline & & & & -.431 & 165.697 & .667 \\
\hline \multirow{2}{*}{$\begin{array}{l}\text { Consumer } \\
\text { Innovation }\end{array}$} & & .354 & .552 & 1.324 & 284 & .187 \\
\hline & & & & 1.334 & 163.772 & .184 \\
\hline
\end{tabular}

When Table 6 is examined, it is seen that there was no significant difference between the marital status variable and the materialist tendencies and consumer innovation variables ( $\mathrm{p}>0.05)$. In this case, $\mathrm{H}_{4}$ and $\mathrm{H}_{5}$ were rejected. 
Determination and Analysis of the Effects of Materialist Tendencies on Consumer Innovation in Terms of Demographic Variables

Table 7. ANOVA Test Results on Materialist Tendencies and Consumer Innovation and Age Variables

\begin{tabular}{lllrrrr}
\hline & \multicolumn{7}{c}{ ANOVA } & & \\
\hline \multirow{2}{*}{ Materialist Tendency } & \multicolumn{7}{c}{ Sum of Squares } & df & Mean Square & F & p \\
\cline { 2 - 7 } & Intergroup & 38.422 & 2 & 19.211 & .128 & .880 \\
\cline { 2 - 7 } & Intragroup & 42539.998 & 283 & 150.318 & & \\
\cline { 2 - 7 } Consumer Innovation & Total & 42578.420 & 285 & & & .431 \\
\cline { 2 - 7 } & Intergroup & 71.636 & 2 & 35.818 & .843 & \\
\cline { 2 - 7 } & Intragroup & 12024.238 & 283 & 42.488 & & \\
\cline { 2 - 7 } & Total & 12095.874 & 285 & & & \\
\hline
\end{tabular}

When Table 7 is examined, it is observed that there was no significant difference between the age variable and materialist tendencies and consumer innovation variables $(p>0.05)$. According to the analysis result, $\mathrm{H}_{6}$ and $\mathrm{H}_{7}$ were rejected.

Table 8. ANOVA Test Results on Materialist Tendencies and Consumer Innovation and Education Variables

\begin{tabular}{lllrrrr}
\hline & \multicolumn{7}{c}{ ANOVA } & & & \\
\hline Variable & & Sum of Squares & df & Mean Square & F & p \\
\hline \multirow{3}{*}{ Materialist Tendency } & Intergroup & 1439.533 & 3 & 479.844 & 3.289 & .021 \\
\cline { 2 - 7 } & Intragroup & 41138.887 & 282 & 145.883 & \\
\cline { 2 - 7 } Consumer Innovation & Total & 42578.420 & 285 & & \\
\cline { 2 - 7 } & Intergroup & 247.068 & 3 & 82.356 & 1.960 & .120 \\
\cline { 2 - 7 } & Intragroup & 11848.806 & 282 & 42.017 & \\
\cline { 2 - 7 } & Total & 12095.874 & 285 & & & \\
\hline
\end{tabular}

When Table 8 is examined, it is seen that while there was a significant difference between the educational status variable and materialist tendencies, there was no significant difference between educational status and consumer innovation $(\mathrm{p}<0.05)$. While $\mathrm{H}_{8}$ was accepted, $\mathrm{H}_{9}$ was rejected. In order to understand from which group the difference arose, group statistics should be examined.

Table 9. Results of Group Statistics Regarding Materialist Tendencies and Consumer Innovation and Education Variables

\begin{tabular}{llrrrr}
\hline Variable & N & Mean & $\begin{array}{c}\text { Standard } \\
\text { Deviation }\end{array}$ & $\begin{array}{c}\text { Standard } \\
\text { Error }\end{array}$ \\
\hline \multirow{3}{*}{$\begin{array}{l}\text { Materialist } \\
\text { Tendency }\end{array}$} & Primary School & 110 & 74.7364 & 12.16000 & 1.15941 \\
\cline { 2 - 5 } & High School & 80 & 71.9000 & 11.85631 & 1.32558 \\
\cline { 2 - 6 } & Associate Degree & 56 & 78.1071 & 13.64841 & 1.82385 \\
\cline { 2 - 6 } & $\begin{array}{l}\text { Bachelor's degree and } \\
\text { higher }\end{array}$ & 40 & 76.7750 & 9.70194 & 1.53401 \\
\cline { 2 - 5 } & Total & 286 & 84.8881 & 12.22285 & .72275 \\
\hline & Primary School & 110 & 12.5727 & 6.70678 & .63947 \\
\hline
\end{tabular}




\begin{tabular}{llllll}
\hline $\begin{array}{l}\text { Consumer } \\
\text { Innovation }\end{array}$ & High School & 80 & 13.2125 & 6.65553 & .74411 \\
\cline { 2 - 5 } & Associate Degree & 56 & 12.1250 & 6.12910 & .81904 \\
\cline { 2 - 5 } & $\begin{array}{l}\text { Bachelor's degree and } \\
\text { higher }\end{array}$ & 40 & 15.1250 & 5.94931 & .94067 \\
\cline { 2 - 5 } & Total & 286 & 13.0210 & 6.51473 & .38522 \\
\hline
\end{tabular}

When the group statistics for the education variable were examined, it was determined that the materialist tendencies were the highest in the consumers with associate degree education and the lowest in the consumers with high school education. Tukey test results are also presented below.

Table 10. Tukey Test Results on the Materialist Tendencies and Education Variable

\begin{tabular}{lrrr}
\hline \multicolumn{3}{c}{ Materialist Tendency } \\
\hline Tukey HSDa,b & \multicolumn{3}{c}{0.05} \\
\hline Education & $\mathrm{N}$ & \multicolumn{2}{c}{$\begin{array}{c}\text { Subset for alpha }= \\
\end{array}$} \\
\cline { 3 - 4 } & & 1 & 2 \\
\hline High School & 80 & 71.9000 & \\
\hline Primary School & 110 & 74.7364 & 74.7364 \\
\hline $\begin{array}{l}\text { Undergraduate/ } \\
\text { Graduate }\end{array}$ & 40 & 76.7750 & 76.7750 \\
\hline $\begin{array}{l}\text { Associate } \\
\text { Degree }\end{array}$ & 56 & & 78.1071 \\
\hline Sig. & & & .113 \\
\hline
\end{tabular}

The Tukey test results shown in Table 10 are the same as the group statistics, and the group with the most materialist tendencies were those who had an associate degree.

Table 11. Results of Group Statistics Regarding Materialist Tendencies and Consumer Innovation and Income Variables

\begin{tabular}{lllrrrr}
\hline & \multicolumn{7}{c}{ ANOVA } & & & \\
\hline Variable & & Sum of Squares & df & Mean Square & F & p \\
\hline \multirow{3}{*}{ Materialist Tendency } & Intergroup & 20.754 & 3 & 6.918 & .046 & .987 \\
\cline { 2 - 7 } & Intragroup & 42557.665 & 282 & 150.914 & & \\
\cline { 2 - 7 } & Total & 42578.420 & 285 & & & \\
\hline \multirow{3}{*}{ Consumer Innovation } & Intergroup & 224.108 & 3 & 74.703 & 1.774 & 0.152 \\
\cline { 2 - 7 } & Intragroup & 11871.766 & 282 & 42.098 & \\
\cline { 2 - 7 } & Total & 12095.874 & 285 & & & \\
\hline
\end{tabular}

When Table 11 is examined, it is observed that there was no significant difference between the income variable and materialist tendencies and consumer innovation variables $(p>0.05)$. In this case, according to the analysis result, $\mathrm{H}_{10}$ and $\mathrm{H}_{11}$ were rejected. 


\section{Conclusion}

In this study, the effect of the materialist tendencies of consumers on consumer innovation was examined. The decisions made by consumers are considered critical to businesses and draw attention to the trends that lead consumers to consumption. In parallel with the rapid changes that occur in consumer tastes, businesses try to make innovations that will enable them to adapt to changes more quickly and meet consumers' demands. For marketers, identifying similarities and differences between consumers is critical. Information about these features contributes to the design of products and services that will attract consumers and to the development of marketing messages. Consumers have a deep desire to be different. People are surrounded by a wide range of goods and services. People spend most of their time working in order to have the power to pay for goods and services. Goods and services have remarkable importance in the eyes of consumers.

As a result of the analyses carried out, a significant relationship between materialist tendencies and customer innovation was determined. It was determined that as the materialistic tendencies of consumers increased, consumer innovation would also increase. As a result of the analyses of the demographic data conducted in the study, no significant difference was found between the gender variable and materialist tendencies, while there was a significant difference in terms of consumer innovation, and consumer innovation tendency was higher in male consumers compared to female consumers. In addition, while a significant difference was observed between the education variable and materialist tendencies, it was revealed that there was no significant difference between education and consumer innovation. The significant difference between the education variable and materialist tendencies arose from the consumers who received associate degree education. Materialist tendencies were found to be higher among consumers with an associate degree. No significant differences were found between marital status, age and income variables, and materialist tendencies and consumer innovation variables.

Some of the studies in the literature on demographic features and materialistic tendencies are as follows; In his study, Kaya (2017) stated that men attach more importance to materiality than women, in addition to the conclusion that the "importance of materiality" dimension shows a significant difference according to the gender of the participants as a result of the Ttest. In addition, according to Anova analysis, materialism does not differ significantly according to the age of the participants.

Manning et al. (1995) emphasized the necessity of testing consumer innovation-seeking and consumer independent decision making on products as individual characteristics. Grewal et al. (2000) stated that social identity has effects on product-based innovativeness. Aydin (2009) stated that consumer innovativeness as a personality trait affects product-based innovativeness positively and significantly. Belbağ and Yilmaz (2017) reveal that consumers seeking for innovation and social identity positively and significantly affect product-based innovativeness.

Bülbül and Özoğlu (2014) revealed that innovativeness has an increasing effect on the purchasing decision of the consumer and there is a positive relationship between consumer innovativeness and purchasing behavior, whereas there is a negative relationship between consumer innovativeness and perceived risk and between perceived risk and purchasing behavior. Aslay et al. (2013), on the other hand, when examining whether there is a relationship between materialism and demographic characteristics, or how the direction of 
this relationship is, they could not find any relationship between attaching importance to materiality and demographic variables. In addition, when they examined the findings of their studies, materialistic behavior was noticed in all demographic groups and they could not find a relationship between living simply and gender, age and monthly income. Accordingly, it can be concluded that women, youth and low-income people tend to live more simply. In this study, it was observed that the gender and age demographic variable does not affect materialist tendencies, only the level of education creates a difference.

Consumers with a high level of cognitive innovativeness prefer products that are practical and appropriate to solve a consumption problem and provide rational benefits (Thorelli and Engledow, 1980: 9). But materialist individuals tend to define themselves and other individuals by the possibilities and possessions they have. They associate being happy and joyful with consumption. Thus, materialism can be characterized as a belief that consumption and shopping lead to happiness. The values belonging to the industrial society have been replaced by post-materialist values. While the important thing in the first value system is the welfare and economic security, the prominent value in the second system is "self-actualization" and "individualism". For this reason, materialists are more prone to debt and more positively towards borrowing than other people. The materialistic tendency is observed in consumers who are influenced by their family, peers, or role models and want to raise awareness in their social environment. For this reason, consumers with a materialistic tendency shop often and exhibit a variety of purchasing styles to buy different products. Consumers acquire social status through consumption and the social status acquired becomes an identity for the consumer. In parallel with this, results obtained from the research show that as the materialist tendencies in consumers increase, consumer innovativeness also increases. For this reason, developing products that may be of interest to materialistic individuals will also trigger consumer innovation, which may increase the demand for the product.

The biggest limitation of the study is that it was limited to the existing questionnaire form and was conducted only in Erzincan. It can be said that the socio-cultural characteristics of the province where the study was carried out were effective in obtaining this result. Therefore, it is not possible to generalize this result to all consumers. Future researchers can carry out new studies in different cities and with a larger sample. In addition, materialistic tendencies and consumer innovation issues can be researched with different variables.

Conducting studies that take into account cultural values, family values, socio-demographic characteristics of the family, and personal differences of consumers in order to further expand the research findings within the scope of the subject of this research will contribute to getting to know the consumer behaviors displayed in shopping environments more closely. Thus, information that will enrich both the market presentations of the implementers and the literature can be obtained. 


\section{References}

Akdoğan, M. Ş., \& Karaarslan, M. H. (2013). Tüketici yenilikçiliği. Atatürk Üniversitesi İktisadi ve İdari Bilimler Dergisi, 27(2), 1-20.

Alan, H., \& Yeloğlu, O. (2013). Markalaşma ve yenilikçilik. Siirt Üniversitesi İktisadi ve İdari Bilimler Fakültesi İktisadi Yenilik Dergisi, 1(1), 13-26

Aslay, F., Ünal, S., \& Akbulut, Ö. (2013). Materyalizmin statü tüketimi üzerindeki etkisini belirlemeye yönelik bir araştırma. Atatürk Üniversitesi İktisadi ve İdari Bilimler Dergisi, 27(2), 43-62.

Aydin, S. (2009). Kişisel ve ürün temelli yenilikçilik: Cep telefonu kullanıcıları üzerine ampirik bir uygulama. Doğuş Üniversitesi Dergisi, 10(2), 188-203.

Aydın. S. (2009). Bireyci-toplumcu. idealist-relativist ve materyalist eğilimler ile hedonik alışveriş arasındaki ilişkiler (Doktora tezi, Afyon Kocatepe Üniversitesi, Afyon). Erişim adresi: http://tez2.yok.gov.tr/

Başar, E. E., \& Yapraklı, Ş. (2013). Tüketici yenilikçiliği ve genişletilmiş teknoloji kabul modelinin e-crm üzerinde etkileri: Bankacılık sektöründe bir uygulama. International Journal of Social Science, 6(6), 149-180

Batory, S.S., Neese, W., \& Batory, A.H. (2005). Ethical marketing practices: An Investigation of antecedents, innovativeness and business performance. Journal of American Academy of Business, 6(2), 135-142.

Belbağ, A. G., \& Yılmaz, K. G. (2017). Fikir liderliği, sosyal kimlik, ürün temelli yenilikçilik ve tüketici yenilikçiliği arasındaki ilişkilerin incelenmesi. In ICPESS (International Congress on Politic, Economic and Social Studies) (No. 3).

Belk, R.W. (1984) Three Scales to measure constructs related to materialism: reliability, validity, and relationships to measures of happiness. Advances in Consumer Research Volume 11, eds. Thomas C. Kinnear, Provo, UT : Association for Consumer Research, Pages: 291297.

Bindah, E. V., \& Othman, M. N. (2011). The role of family communication and television viewing in the development of materialistic values among young adults. A review. International Journal of Business and Social Science, 2(23), 238-248.

Blake, B., Perloff, R., \& Heslin, R. (1970). Dogmatism and acceptance of new products. Journal of Marketing Research, 7(4), 483-486.

Bocock, R. (2009). Tüketim. (Çeviren: İrem Kutluk). Ankara: Dost Yayınları.

Bruce, G. D., \& Witt, R. E. (1970). Personality correlates of innovative buying behavior. JMR, Journal of Marketing Research (pre-1986), 7(000002), 259.

Bülbül, H., \& Özoğlu, B. (2014). Tüketici yenilikçiliği ve algılanan riskin satın alma davranışına etkisi. Erciyes Üniversitesi İktisadi ve İdari Bilimler Fakültesi Dergisi, (44), 43-58.

Cowart, K. O., Fox, G. L., \& Wilson, A. E. (2008). A structural look at consumer innovativeness and selfcongruence in new product purchases. Psychology \& Marketing, 25(12), 1111-1130.

Doğan. Y. S. (2010). Materyalist eğilimlerin demografik özelliklerine göre farklılaşmasına yönelik bir araştırma. Cumhuriyet Üniversitesi İktisadi ve İdari Bilimler Dergisi, 11(1), 57-70.

Eastman, J. K., Fredenberger, B., Campbell, D., \& Calvert, S. (1997). The relationship between status consumption and materialism: A cross cultural comparison of chinese, Mexican, and American students. Journal of Marketing Theory E Practice, 5, 52-65.

Eryiğit, C., \& Kavak, B. (2011). Tüketici yenilikçiliğinin tutumsal ve davranışsal uyumunun incelenmesi", Hacettepe Üniversitesi. İktisadi ve İdari Bilimler Fakültesi Dergisi, 29(2), 95-113. 
Feldman, L. P., \& Armstrong, G. M. (1975). Identifying Buyers of a Major Automotive Innovation: The introduction of the rotary-engined Mazda offers a unique opportunity to study consumer innovators. Journal of Marketing, 39(1), 47-53.

Fitzmaurice J., \& Comegys C. (2006). Materialism and social consumption. Journal of Marketing Theory and Practice, 14(4), 287-299.

Ger. G., \& Belk. W. R. (1996). Cross cultural differences in materialism. Journal of Economic Pyschology, 17(1), 55-77.

Goldsmith, R. E., \& Hofacker, C. F. (1991). Measuring consumer innovativeness. Journal of the Academy of Marketing Science, 19(3), 209-221.

Goldsmith, R.E., \& Flynn, 1.R. (1993). Models of enduring product involvement and opinion leadership in swift". Association of Marketing Theory and Practice Proceedings, 2, 378-386

Grewal, R., Mehta, R., \& Kardes, F. R. (2000). The role of the socialidentity function of attitudes in consumer innovativeness and opinion leadership. Journal of Economic Psychology, 21(3), 233-252.

Güleş, H. K., \& Bülbül, H. (2004). Yeni ürün performansının artırılmasında ürün geliştirme yöntemlerinin etkisi: Sanayi İşletmelerinde Bir Saha Araştırması. Atatürk Üniversitesi İktisadi ve İdari Bilimler Dergisi, 18(1/2), 147-167.

Heaney, J.G., Goldsmith, R.E., \& Jusoh, W.J.W. (2005). Status consumption among malaysian consumers: exploring its relationship with materialism and attention to social camparision information. Jurnal of International Consumer Marketing, 17(4), 83-98.

Hirunyawipada, T., \& Paswan, A. K. (2006). Consumer innovativeness and perceived risk: implications for high technology product adoption. Journal of Consumer Marketing, 23(4), 182-198

Hudders L., \& Pandelaere M. (2012). The silver lining of materialism: The impact of luxury consumption on subjective well-being. J Happiness Study, (13), 411-437.

Hulin, C.,Netemeyer, R., \& Cudeck, R. (2001). Can a reliabilitycoefficient be toohigh? Journal of Consumer Psychology, 10(1), 55-58.

Im, S., Mason, C. H., \& Houston, M. B. (2007). Does innate consumer innovativeness relate to new product/service adoption behavior? The intervening role of social learning via vicarious innovativeness. Journal of the Academy of Marketing Science, 35, 63-75.

Kasser, T. (2018). Materialism and Living Well., 1-12. https://www.nobascholar.com/chapters/48/download.pdf, Erişim Tarihi: 13.09.2019.

Kaya, C. (2017). Ulusal ve uluslararası giyim markaların satın alma niyeti üzerinde etnosentrizm, materyalizm ve dindarlı̆̆ın etkisi (Yüksek lisans tezi, Yıldız Teknik Üniversitesi İstanbul). Erişim adresi: http://tez2.yok.gov.tr/

Kılıçer, K., \& Odabaşı, H. F. (2010). Bireysel yenilikçilik ölçeği (BYÖ): Türkçeye uyarlama, geçerlik ve güvenirlik çalışması. Hacettepe Üniversitesi Ĕ̆itim Fakültesi Dergisi, 38, 150-164

Manning, K. C., Bearden, W. O., \& Madden, T. J. (1995). Consumer innovativeness and the adoption process. Journal of Consumer Psychology, 4(4), 329-345.

Merchant, A., Rose, G., \& Rose, M. (2014). The impact of time orientation on consumer innovativeness in the United States and India, Journal of Marketing Theory and Practice, 11(3), 325-337.

Midgley, D.F., \& Dowling, G.R. (1978). Innovativeness: The concept and its measurement. Journal of Consumer Research, 4(4), 229-242.

Nepomuceno M., \& Laroche M. (2015). The impact of materializm and anti-consumption lifestyles on personl debt and account balances". Journal of Business Research, (68), 654-664. 
Odabaşı, Y. (2017). Postmodern pazarlama, tüketim ve tüketici. İstanbul: MediaCat Yayınları.

Odabaşı, Y., \& Barış, G. (2002). Tüketici davranışları. İstanbul: Mediacat Yayınları.

Odabaşı. Y. (2013). Tüketim kültürü̈. İstanbul: Sistem Yayıncılık.

Özer, G., Serkan, A., \& Murat, Ö. (2009). Muhasebecilerin marka algıları ve tüketici özelliklerinin (yenilikçilik ve fikir liderliği) uzun dönemde müşteri-marka ilişkisini belirleyen faktörler üzerine etkisi. İş, Güç Endüstri İlişkileri ve İnsan Kaynakları Dergisi, Temmuz/July, 11(3), 113-130

Peat, N. C., Gentry, J. W., \& Brown, T. L. (1975). A Comment on "Identifying Buyers of a Major Automotive Innovation". Journal of marketing, 39(4), 61-62.

Pizam, A. (1972). Psychological characteristics of innovators. European journal of marketing.

Porter, M. E. (1998). The competitive advantage of nations, London: MacMillan Press Ltd.,

Richins M. L., \& Dawson S. (1992). A consumer values orientation for materialism and its measurement: Scale development and validation, Journal of Consumer Research, 19(3), 303316.

Robertson, T. S., \& Myers, J. H. (1969). Personality correlates of opinion leadership and innovative buying behavior. Journal of Marketing Research, 6(2), 164-168.

Rogers, E., \& Shoemaker, F. (1971). Communication of Innovations: A cross cultural approach, New York: Free Press.

Sevgili. F. (2012). Değerler tüketim ilişkisinde materyalizm ve değgr-eşya temsilinin aracı rolü (Yüksek lisasn tezi, İstanbul Üniversitesi, İstanbul). Erişim adresi: http://tez2.yok.gov.tr/

Steenkamp, J., Benedict E. M., Hofstede, F., \& Wedel, M. (1999). A cross national investigation into the individual and national cultural antecedens of consumer innovativeness. Journal of Marketing, 63(2), 55-69.

Tatham, R. L., \& Dornoff, R. J. (1973). A cautionary note on innovative overlap. JMR, Journal of Marketing Research (pre-1986), 10(000002), 224.

Thorellı, HB., \& Engledow, JL. (1980). Information seekers and information system: A policy perspective. Journal of Marketing, 44, 9-27

Titay. M. A., \& Torlak. Ö. (2011). Materyalist eğilim. Dini değerler. Marka bağlılığı ve tüketici ahlakı arasındaki ilişkiler. İş Ahlakı Dergisi, 4(7), 93-130.

Vandecasteele, B., \& Geuens, M. (2010). Motivated consumer innovativeness: concept, measurement, andvalidation intern. Journal of Research in Marketing, (27), 308-318.

Venkatraman, M. P. (1991). The impact of innovativeness and innovation type on adoption. Journal of Retailing, 67(1), 51-67.

Ventura, K. (2003). Pazarlama araştırmaları kapsamında yaşanan teknoloji-tabanlı değişim. Ege Academic Review, 3(1), 78-89.

Watson, J. J. (2003). The relationship of materialism to spending tendencies, saving, and debt, Journal of Economic Psychology, 24, 723-739.

Xie, Y.H., \& Singh, N. (2007). The impact of young adults' socialisation on consunfier innovativeness. Journal of Customer Behaviour, 6(3), 229-248. 